\title{
The Influence of Energy Recovery from Waste on Landfill Gas: A Case Study from Korea
}

\author{
DaEun Kim, DaeWon Pak, Seung-Kyu Chun* \\ Graduate School of Energy and Environment, Seoul National University of Science and Technology, \\ Seoul, South Korea
}

Received: 27 August 2017

Accepted: 17 December 2017

\begin{abstract}
In order to conceive of an efficient way to manage a landfill, we conducted an exemplary study of the Sudokwon Landfill Site in South Korea, with particular regard to the influence of energy recovery from waste. As a result of the BMP test, biogas production of demolition waste was much lower than household waste even in the same waste type. Gas production from the residual substance of energy recovery from waste (ash), waste soil, and the sludge landfill cover material was almost zero, but the solidified sludge showed 4.1 times greater than digested sludge due to the fewer pozzolanic reactions. Lysimeter test results show that the total amount of landfill gas was reduced to about $1 / 27$ when combustible waste is buried after the recovery of energy, but, in order to be able to completely eliminate the landfill gas collecting system in a newly managed landfill, solidified sludge should not be disposed of in the landfill site. In addition, the maximum concentration of hydrogen sulfide was $60.9 \times 10^{3} \mathrm{ppm}$, when total waste was mixed and landfilled. However, the concentration of hydrogen sulfide decreased to about $1 / 6$ and the total load largely decreased to about $0.9 \%$ when applied to landfill waste after energy recovery.
\end{abstract}

Keywords: landfill, energy recovery, BMP test, Lysimeter, solidified sludge

\section{Introduction}

The volume and composition of landfill gas (LFG) [1] as a product of biochemical degradation in the landfill during landfill disposal [2] has a great impact on the operation of a landfill [3]. Therefore, in order to operate landfill sites economically and in an environmentally friendly manner, the characteristics of landfill wastes should be identified prior to demolition planning and operation of the landfill sites. The amount and nature of LFG vary greatly depending on the energy recovery and recycling projects for landfill waste. In other words, if

*e-mail: skchun@seoultech.ac.kr waste energy recovery is carried out before waste landfill, then the inorganic waste after waste pretreatment and residue from the thermochemical energy recovery are left as landfill waste. Therefore, the volume of LFG generated differs in direct landfills where energy recovery is not carried out. In addition, whether or not landfilling solidified sludge [4-5], mixed landfilling of the total wastes, and the separate landfilling of specific wastes are carried out also affect LFG output.

The influence of the traditional method of direct landfilling of total wastes on the characteristics of the landfill such as LFG production due to energy recovery and separate reclamation of the waste materials can be estimated, making it possible to better plan the energy recovery system and energy recycling projects [6]. 
Also, it can be helpful to operate the landfill in a more economical and rational way. The purpose of this study is to investigate the Sudokwon Landfill Site 2 (LS2) in Korea from this perspective.

The LS2 is the second landfill within the Sudokwon Landfill Site (SLS) on the west coast of Korea. The landfill began operation in October 2000 and will be terminated at the end of 2018 since Landfill Site 3 (LS3) will be opened to begin operation in 2019. In addition, the planning of LS3 is mainly focused on streamlining the operation by applying separation and sorting processes to wastes before landfill disposal, and disposing of wastes only after undergoing an energy recovery system according to the Framework Act on Resource Circulation that came into effect in South Korea on 1 January 2018.

In this study, two different experiments were performed: the biochemical methane potential (BMP) tests [7] and the lysimeter test [8-9]. As a result, we analyzed the effects of applying the same condition of energy recovery projects using incoming household and demolition wastes of LS2 on the production of LFG and hydrogen sulfide $\left(\mathrm{H}_{2} \mathrm{~S}\right)$ of LS3 in the future.

\section{Materials and Methods}

\section{Study Site}

SLS collects household waste, demolition waste, and sewage sludge from about 20 million people in the Seoul, Incheon, and Gyeonggi areas. Household and demolition wastes are landfilled directly without pre-treatment. The annual load of 3,000 Mg/d of sewage sludge is used for dry fuel conversion for $1 / 3$ of the amount, and solidified sludge (SS) for the other $1 / 3$, with the rest being used for sludge landfill cover material (SLCM). The direct landfill disposal of sludge is prohibited by the Wastes Control Act of Korea, so it is solidified as SS before landfill disposal. SLCM is produced by solidifying sludge [10] for use in daily and intermediate cover soil. Daily cover soil is carried out with the purpose of preventing scattering of waste, odor, and insect pests when the daily landfill disposal is completed, and the intermediate cover soil is used for environmental management after the midcompletion of a landfill, due to any interruptions by natural conditions such as rain. In Korea, the intermediate cover soil thickness is set to $30 \mathrm{~cm}$ or more (LS2 is $50 \mathrm{~cm}$ or more) by the Wastes Control Act. LS2 uses this SLCM in addition to soil for daily and intermediate coverings.

The LS2 area is $2.5 \mathrm{~km}^{2}$, which is a sandwich-type landfill with a total landfill capacity of $86.7 \times 10^{6} \mathrm{~m}^{3}$. It is designed with 8 layers (each layer: waste $4.5 \mathrm{~m}$ and intermediate cover $0.5 \mathrm{~m}$ ), each with 25 blocks $(300 \times 300 \mathrm{~m}$ per block). In addition, it also contains 669 landfill gas collecting vertical wells, a 36$\mathrm{km}$ horizontal collecting pipe conduit, 44 manifold stations to control collecting pressure, a $50 \mathrm{MW} \mathrm{LFG}$ power plant (steam turbine), and a leachate treatment facility $\left(6,700 \mathrm{~m}^{3} /\right.$ day $)$ constructed with nitrificationdenitrification applications [11]. Table 1 shows the amount of landfill wastes, the production of LFG, and the leachate in LS2 as of 2014.

\section{Methods for the Experiment}

\section{BMP Test}

A BMP test was carried out in order to determine the biogas production potential of the landfill waste materials. In this study, a total of 18 individual and combination waste materials were studied; of these, 14 were singletype wastes studied over 35 days and included household waste (food, paper, wood, fiber, other), demolition waste (paper, wood, fiber), sludge waste, non-digested sludge (NDS), digested sludge (DS), SS, SLCM), ash, and waste soil that comes from the mechanical sorting process of demolition waste. The remaining four BMP tests were combinations of residues from energy recovery, and the last case where separate landfill disposal of demolition waste is allowed. Specifically, a combination of SS and waste soil (B1), a combination of the SLCM and waste soil (B2), a combination of the ash and the waste soil (B3), and the other would be separate landfill disposal of demolition waste (B4). In the last 4 combinations of the BMP test, the volume of the nutrient medium and sludge was increased to more than the other of the BMP test for ease of the experiment. In addition, considering the fact that it is a scenario-based experiment of combinations of landfill wastes, $\mathrm{pH}$ control using hydrochloric acid or sodium hydroxide or the control of alkalinity using

Table 1. Landfill waste, landfill gas, and leachate of LS2 (2014).

\begin{tabular}{|c|c|c|c|c|c|c|}
\hline \multicolumn{5}{|c|}{ Landfill Waste $\left(10^{3} \mathrm{Mg}\right)$} & \multirow{2}{*}{$\begin{array}{l}\text { Landfill Gas } \\
\qquad\left(10^{3} \mathrm{~m}^{3}\right)\end{array}$} & \multirow{2}{*}{$\begin{array}{c}\text { Leachate }^{6} \\
\left(10^{3} \mathrm{~m}^{3}\right)\end{array}$} \\
\hline Total & Household $^{1}$ & Demolition $^{2}$ & $\mathrm{Ash}^{3}$ & Treated sludge ${ }^{4}$ & & \\
\hline 2,431 & 726 & 1,186 & 148 & 370 & 269,819 & 529 \\
\hline $100.0(\%)$ & 29.9 & 48.8 & 6.1 & 15.2 & & \\
\hline
\end{tabular}

1) Combustibles: $94.1 \%$

2) Combustibles: $50.4 \%$, waste soil $20.0 \%$

3) Bottom ash from external incinerators

4) Treated sludge: Solidified sludge and sludge landfill cover material (50\% respectively)

5) $\mathrm{CH}_{4} 47.1 \%, \mathrm{CO}_{2} 39.3 \%, \mathrm{~N}_{2} 13.2 \%, \mathrm{O}_{2} 0.4 \%$

6) BOD $248 \mathrm{mg} / \mathrm{L}, \mathrm{COD} 2,032 \mathrm{mg} / \mathrm{L}, \mathrm{TN} 1,705 \mathrm{mg} / \mathrm{L}, \mathrm{NH}_{4}^{+}{ }^{+} \mathrm{N} 1,562 \mathrm{mg} / \mathrm{L}$ 


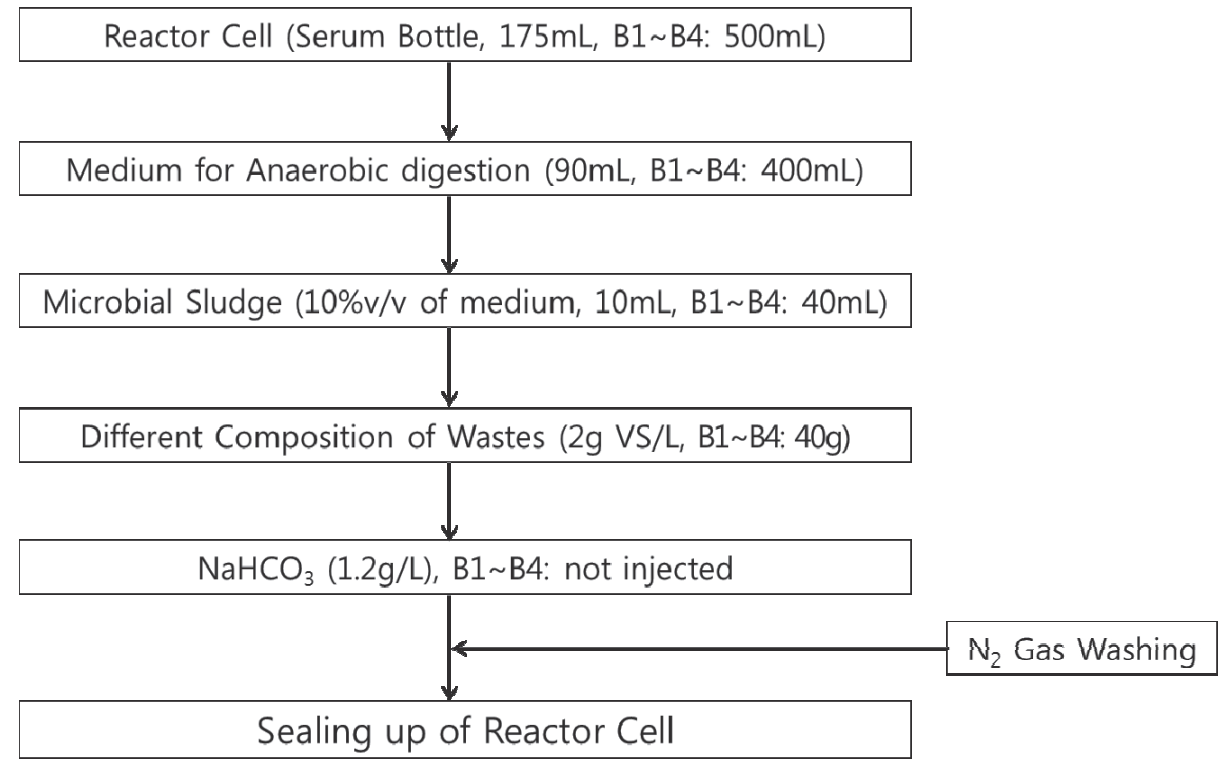

Fig. 1. Procedure of BMP test for each waste type.

bicarbonate is excluded to make the waste condition closer to the decomposition environment in the actual landfill. The experiment lasted 51 days, which is longer than the duration of the 14 single type waste BMP tests.

The analysis of composition of volatile solids (VS) and the amount of biogas production from all the 18 different BMP tests were performed in triplicate and the mean values were calculated [12]. The anaerobic DS from the sludge digestion tank of the wastewater treatment plant was used to conduct the anaerobic microbial strains. The experiment was carried out at $35^{\circ} \mathrm{C}$. The entire experimental procedure is shown in Fig. 1.

The volume of biogas generated from the 18 BMP test bottles was corrected by excluding the amount of cumulative gas of the blank sample, which was carried out with only anaerobic digestion sludge and substances in it. In addition, Eq. 1 was used to remove the amount of gas present in the headspace before sampling, and Eq. 2 was used to convert it into biogas in conditions of dry and standard temperature and pressure (STP).

$$
V_{35}=C_{1} \times\left(V_{0}+V_{1}\right)-C_{0} V_{0}
$$

$V_{35}$ : Biogas emission volume at $35^{\circ} \mathrm{C}(\mathrm{mL})$

$C_{l}$ : Gas concentration at the time of sampling (\%)

$C_{0}$ : Gas concentration at the time of previous sampling $(\%)$

$V_{0}:$ Volume of the upper space of the rector $(\mathrm{mL})$

$V_{1}$ : Gas volume measured by a syringe $(\mathrm{mL})$

$$
V_{S T P}=V_{35} \times \frac{273}{273+35} \times \frac{760-42.2}{760}
$$

$V_{S T P}$ : Volume of gas generation $(\mathrm{NmL})$ under standard conditions $\left(0^{\circ} \mathrm{C}, 1 \mathrm{~atm}\right)$

42.2: Saturated water vapor pressure at $35^{\circ} \mathrm{C}(\mathrm{mmHg})$

\section{Lysimeter Experiment}

The amount of LFG production mainly affects the LFG collecting system, power plant using LFG, and landfill covering systems for suppressing LFG surface emissions [13-14]. If the amount of LFG is insufficient to secure the economic viability of the LFG power generation business, it will incur costs for the LFG collection system and the cover soil system, which will then hinder the operational efficiency of the landfill. Therefore, if the LFG generation cannot meet the secure level of the LFG to run an economically efficient LFG power generation facility, it is necessary to simplify landfill gas capture and cover soil systems through thorough energy conversion, resource reclamation, and pre-treatment processes. Therefore, the lysimeter experiments [15-16] were conducted in order to determine the level of LFG gas generation in different scenarios.

Lysimeter tests were performed in 2 cases of L1 and L2: a case in which the lysimeter filling material composition is exactly the same as LS2 waste composition (L1), and another case where the household and demolition waste materials from the total income waste of LS2 were supposedly under energy recovery and only the residues from it were disposed of in landfill (L2). As shown in Table 1, L1 was filled with household waste, demolition waste, SS, SLCM, and ash. L2 was filled with SS, SLCM, ash, and waste soil. In addition, the ash of L2 consists of the bottom ash imported from external incinerators outside of SLS such as L1, and the ash generated in SLS after the energy recovery processes of household waste and the combustibles from demolition waste.

The lysimeter was designed to be $0.2 \mathrm{~m}$ in diameter, $0.85 \mathrm{~m}$ in height, and $0.027 \mathrm{~m}^{3}$ in volume, and made up of acryl as shown in Fig. 2. The amount of filling waste material is $10.4 \mathrm{~kg}$ for L1 and $10.3 \mathrm{~kg}$ for L2. Considering 


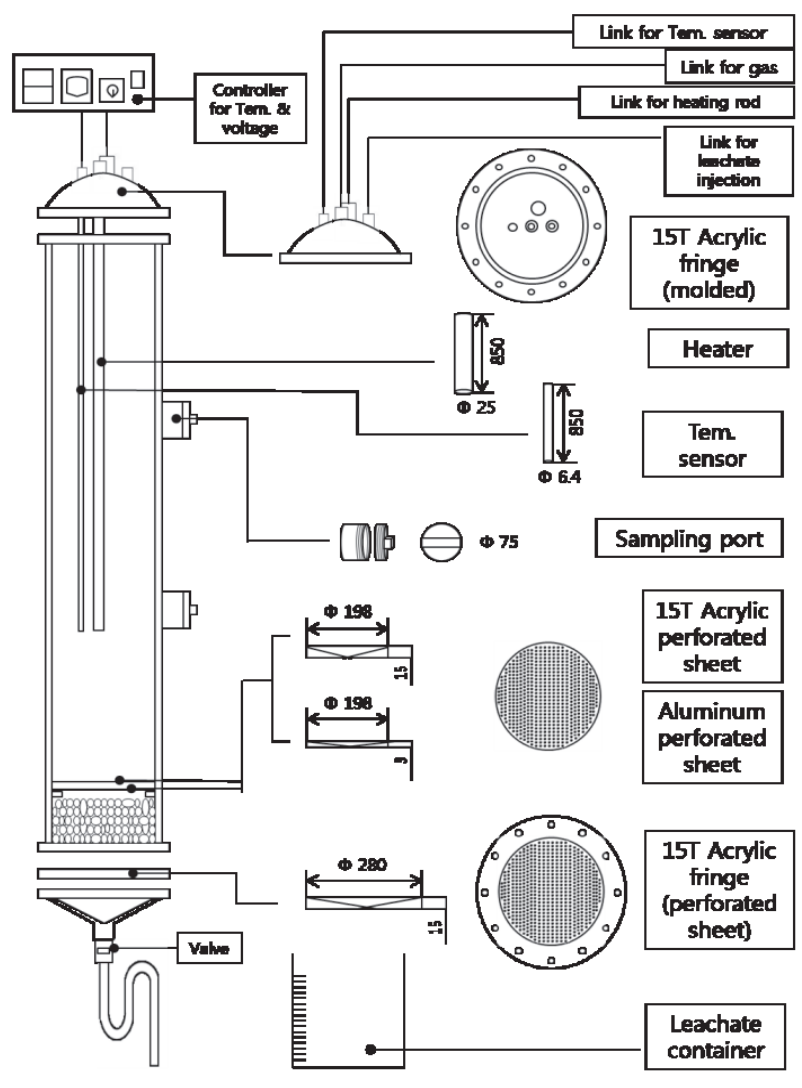

Fig. 2. Design for lysimeter.

that the lysimeter experiment needs a long time, the optimal conditions preceded by in order to expedite the experiment. That is, the particle size was made as small as possible and a thermostat was installed to maintain proper temperature $\left(35 \pm 1^{\circ} \mathrm{C}\right)$ during the experiment.

In addition, the leachate that leached down was recycled to the top of the same lysimeter to keep the optimum moisture content and substrate retention. A digital flow meter was installed in the upper gas connection part of the reactor to analyze the amount of gas collected online in real time. The experiment proceeded 205 days when the amount of gas generation was reduced enough.

\section{Waste Materials for Reactor Filling and Analysis Items}

The waste materials were sampled by a waste characterization survey conducted by SLS in 2014, and
Table 3. Types of waste materials and the analysis items for all experiments.

\begin{tabular}{|c|c|c|}
\hline Experiment & Filled waste & $\begin{array}{l}\text { Analysis } \\
\text { item }^{5}\end{array}$ \\
\hline \multirow{2}{*}{ BMP } & $\begin{array}{l}\text { Household waste (food, paper, } \\
\text { wood, textile, other) } \\
\text { Demolition waste (paper, wood, } \\
\text { textile) } \\
\text { Sludge (NDS, DS, SS, SLCM) }{ }^{1} \\
\text { Ash, Waste soil }{ }^{2}\end{array}$ & $\mathrm{CH}_{4}, \mathrm{CO}_{2}$ \\
\hline & $\begin{array}{c}\text { B1 : SS+Waste soil } \\
\text { B2 : SLCM+Waste soil } \\
\text { B3 : Ash }{ }^{3}+\text { Waste soil } \\
\text { B4 : The same composition of } \\
\text { demolition waste of LS2 } \\
\text { (paper, wood, textile, waste soil) }\end{array}$ & $\mathrm{CH}_{4}, \mathrm{CO}_{2}$ \\
\hline Lysimeter & $\begin{array}{l}\text { L1 : The same composition of LS2 } \\
\text { (household and demolition waste, } \\
\text { SS, SLCM, Ash }{ }^{4} \text { ) } \\
\text { L2: } \text { Ash }^{3}+\text { SS+SLCM+Waste soil }\end{array}$ & $\begin{array}{c}\mathrm{CH}_{4}, \\
\mathrm{CO}_{2}, \mathrm{H}_{2} \mathrm{~S}\end{array}$ \\
\hline
\end{tabular}

1) NDS: Non-digested sludge, DS: Digested sludge, SS: Solidified sludge, SLCM: Sludge landfill cover material

2) Soil and cement debris from energy and material recovery from demolition waste

3) Incomed and energy recovery residue as subtotal in Table 3

4) Bottom ash from external incinerators

5) $\mathrm{CH}_{4}, \mathrm{CO}_{2}$ analysis: GC/TCD (Thermal Conductivity Detector), $\mathrm{H}_{2} \mathrm{~S}$ : GC/PFPD (Pulsed Flame Photometric Detector, 5380)

SS and SLCM were collected from each production facility in SLS. The filling ratio of L1 is equal to the total landfill waste composition of the LS2 in 2014, and B4 is equal to the actual landfill composition for demolition waste. In the case of $\mathrm{L} 2$ and $\mathrm{B} 1 \sim \mathrm{B} 3$, the estimated rate of the different composition of landfill waste according to expected energy recovery was applied. In fact, in the case of L2 and B3, the amount of ash generated after recovering energy for combustibles of household and demolition wastes is assumed to be $10 \%$ of the combustibles. The amount of waste soil in demolition waste, which contains a large amount of sulfate (which can have great influence on the production of $\mathrm{H}_{2} \mathrm{~S}$ ), was applied to $20.0 \%$ of the 2014 survey result. Sludge is applied to the total annual production rate of SS and SLCM in SLS at a ratio of about $1: 1$ in 2014.

Non-biodegradable organic matter like plastics and incombustible materials such as bricks and glass

Table 2. Ratio and amount of waste materials for lysimeter reactors $\left(10^{3} \mathrm{Mg}\right)$.

\begin{tabular}{|c|c|c|c|c|c|c|c|}
\hline \multirow{2}{*}{ Waste type } & \multicolumn{2}{|c|}{ Biodegradable } & \multirow{2}{*}{ Waste soil } & \multirow{2}{*}{$\begin{array}{c}\text { Sludge } \\
\text { (SS and SLCM) }\end{array}$} & \multicolumn{3}{|c|}{ Ash } \\
\cline { 2 - 6 } & Household & Demolition & & Subtotal & Internal $^{1}$ & External $^{2}$ \\
\hline Landfill quantity & 684 & 599 & 237 & 370 & 273 & 125 & 148 \\
\hline Ratio & 2.88 & 2.53 & 1.00 & 1.56 & 1.15 & 0.53 & 0.62 \\
\hline
\end{tabular}

1) Ash left from the energy recovery of SLS incomed household and demolition wastes

2) Ash from other incineration facilities outside of SLS 
Table 4. BMP test results of each waste type.

\begin{tabular}{|c|c|c|c|c|c|c|c|}
\hline \multirow{2}{*}{\multicolumn{2}{|c|}{ Waste type }} & \multicolumn{3}{|c|}{ Unit wet waste base $(\mathrm{mL} / \mathrm{g})$} & \multicolumn{3}{|c|}{ VS base (mL/g VS) } \\
\hline & & \multirow{2}{*}{$\begin{array}{c}\text { Total } \\
64.6\end{array}$} & \multirow{2}{*}{$\begin{array}{l}\mathrm{CH}_{4} \\
41.8 \\
\end{array}$} & \multirow{2}{*}{$\begin{array}{l}\mathrm{CO}_{2} \\
22.8\end{array}$} & \multirow{2}{*}{$\begin{array}{l}\text { Total } \\
230.7\end{array}$} & \multirow{2}{*}{$\begin{array}{c}\mathrm{CH}_{4} \\
149.3\end{array}$} & \multirow{2}{*}{$\begin{array}{l}\mathrm{CO}_{2} \\
81.4\end{array}$} \\
\hline \multirow{5}{*}{ Household } & Food & & & & & & \\
\hline & Paper & 296.1 & 184 & 112.1 & 339.1 & 210.7 & 128.4 \\
\hline & Wood & 220.8 & 132.3 & 88.5 & 236.3 & 141.6 & 94.7 \\
\hline & Textile & 299.6 & 169.8 & 129.8 & 239.6 & 135.8 & 103.8 \\
\hline & Other & 55.4 & 35.2 & 20.2 & 77.5 & 49.3 & 28.2 \\
\hline \multirow{3}{*}{ Demolition } & Paper & 100.3 & 61.8 & 38.5 & 150.6 & 92.8 & 57.8 \\
\hline & Wood & 35.3 & 21.5 & 13.8 & 49.5 & 30.1 & 19.4 \\
\hline & Textile & 155.0 & 104.1 & 50.9 & 179.7 & 120.7 & 59.0 \\
\hline \multirow{4}{*}{ Sludge } & NDS & 44.9 & 30.3 & 14.6 & 285.1 & 192.2 & 92.9 \\
\hline & DS & 2.9 & 1.9 & 1.0 & 25.1 & 16.3 & 8.8 \\
\hline & SS & 29.6 & 20.7 & 8.9 & 102.3 & 71.5 & 30.8 \\
\hline & $\mathrm{SLCM}^{1)}$ & 0.0 & 0.0 & 0.0 & 0.0 & 0.0 & 0.0 \\
\hline \multirow{2}{*}{ Residue from $\mathrm{R}^{2)}$} & $\operatorname{Ash}^{1)}$ & 0.0 & 0.0 & 0.0 & 0.0 & 0.0 & 0.0 \\
\hline & Waste soil ${ }^{1)}$ & 0.0 & 0.0 & 0.0 & 0.0 & 0.0 & 0.0 \\
\hline \multirow{4}{*}{$\begin{array}{l}\text { Landfill by residue } \\
\text { \& separation }\end{array}$} & B1 & 12.78 & 9.04 & 3.74 & 82.43 & 58.31 & 24.12 \\
\hline & B2 & 0.11 & 0.06 & 0.05 & 0.94 & 0.52 & 0.42 \\
\hline & B3 & 0.02 & 0.01 & 0.01 & 0.12 & 0.07 & 0.05 \\
\hline & B4 & 3.84 & 2.26 & 1.58 & 7.6 & 4.48 & 3.12 \\
\hline
\end{tabular}

1) Under measurement limit.

2) R: Recovery of energy and resource

from household and demolition wastes that are not much influence on LFG production are excluded from the materials to be filled for efficient experimentation. Table 2 shows the filling ratios of the waste materials for lysimeter reactors. When filling the L2 and B1 B3 reactors, the ratios shown in Table 2 were applied to all experimental reactors regardless of the absolute feeding quantity. Table 3 summarizes the types of waste materials and analysis items applied to all experiments, including BMP and lysimeter.

\section{Results and Discussion}

\section{The Amount of Gas Produced by Each Waste and Landfill Combination}

Table 4 shows the results of the BMP test for each of the waste materials found in LS2 wastes, the combinations of residues after waste energy recovery, and the separate landfill disposal of demolition waste. The largest biogas production per volatile solid (VS) unit weight came from paper in the household waste, while the biogas generation in the SLCM, ash, and waste soil was below the measurement level. It is interesting to note that even though waste materials are classified as the same types between household and demolition wastes, the amount of gas generated from the waste materials of demolition waste is smaller than that from the same types of the household wastes such as paper and wood. Especially in the case of wood, the difference between the two was very large.

Table 5 shows the results of element analysis and triple component analysis (water, combustibles, incombustibles) for each component of the BMP test samples. The compositions of homogenous waste materials such as paper, wood, and fiber that mainly affect gas generation between the household and demolition wastes are similar. But when the physical and elemental analysis results are considered, then the demolition waste is somewhat disadvantageous to gas generation compared to household waste. However, this difference was not as large as the difference in gas generation from the BMP test. It is considered that household wastes and demolition wastes have different biodegradation levels due to the presence of biological degradation inhibitors in organic matter such as paper, wood, and fiber, making evaluations through only elemental analysis difficult. In particular, preserved wood [17] accounts for a large proportion of wood 
Table 5. Physical and element analysis values of household and demolition waste (unit: weight \%).

\begin{tabular}{|c|c|c|c|c|c|c|c|c|c|c|c|c|}
\hline \multirow{2}{*}{\multicolumn{2}{|c|}{ Waste type }} & \multicolumn{5}{|c|}{ Combustibility } & \multicolumn{6}{|c|}{ Major elements } \\
\hline & & \multirow{2}{*}{$\begin{array}{c}\text { Moisture } \\
65.6\end{array}$} & \multirow{2}{*}{$\begin{array}{c}\text { Ignition loss } \\
89.1\end{array}$} & \multirow{2}{*}{$\frac{\mathrm{TS}}{34.4}$} & \multirow{2}{*}{$\frac{\mathrm{VS}}{31.1}$} & \multirow{2}{*}{$\begin{array}{l}\text { FS } \\
3.3\end{array}$} & \multirow{2}{*}{$\begin{array}{r}\text { Total } \\
86.74\end{array}$} & \multirow{2}{*}{$\frac{C}{44.91}$} & \multirow{2}{*}{$\frac{\mathrm{H}}{6.65}$} & \multirow{2}{*}{$\frac{\mathrm{O}}{31.86}$} & \multirow{2}{*}{$\frac{\mathrm{N}}{3.33}$} & \multirow{2}{*}{$\begin{array}{c}S \\
0.10\end{array}$} \\
\hline \multirow{5}{*}{ Household } & Food & & & & & & & & & & & \\
\hline & Paper & 17.8 & 89.7 & 82.2 & 73.7 & 8.5 & 89.73 & 39.06 & 5.47 & 35.21 & 0.80 & 0.10 \\
\hline & Wood & 12.2 & 99.3 & 87.8 & 87.1 & 0.7 & 94.30 & 46.7 & 6.00 & 41.61 & 0.40 & 0.00 \\
\hline & Textile & 7.3 & 98.4 & 92.7 & 91.2 & 1.5 & 99.11 & 56.16 & 5.49 & 36.41 & 0.22 & 0.84 \\
\hline & Other & 12.8 & 20.7 & 87.2 & 18.2 & 69.0 & 44.14 & 19.15 & 2.08 & 21.63 & 1.29 & 0.10 \\
\hline \multirow{4}{*}{ Demolition } & Paper & 23.6 & 74.4 & 76.4 & 56.9 & 19.5 & 77.99 & 32.38 & 4.62 & 39.71 & 0.38 & 0.91 \\
\hline & Wood & 17.8 & 90.7 & 82.2 & 74.6 & 7.6 & 92.23 & 44.75 & 5.34 & 41.51 & 0.64 & 0.10 \\
\hline & Textile & 11.0 & 77.1 & 89.0 & 68.5 & 20.5 & 92.27 & 48.41 & 5.01 & 35.88 & 1.21 & 1.77 \\
\hline & Waste soil & 17.6 & 12.7 & 82.4 & 10.4 & 72.0 & 21.37 & 4.23 & 0.35 & 12.94 & 0.26 & 3.50 \\
\hline
\end{tabular}

waste in demolition waste, which is very unfavorable to biodegradation.

In the case of sludge, NDS produced the greatest amount of gas per unit VS, and it was 11.4 times that of DS, which already processed residual sludge from digestion for biogas production for energy recovery. In the SLS, the SS is produced from NDS, and the SLCM is made from DS using the solidification method by pozzolanic reaction [18].

Table 6 shows the amount and composition of the solidifying agents used for SS and SLCM. The solidifying agents addition by weight ratio of agents to sludge, 100 to 20 in SS and 100 to 48 in SLCM. In the case of SS, the amount of solidifying agent is less than that of SLCM, especially in the Ca ratio. Therefore, SS is not believed to cause sufficient immobilization of organic matter in the sludge by pozzolanic reaction. The SS facilitates the embedding work of landfills by improving the water ratio and physical properties of the sludge rather than the organic matter immobilization itself. For this reason, there was no SLCM gas generation in the BMP test, while the amount of gas per unit VS of SS was 4.1 times that of the DS and $35.9 \%$ of the NDS.

The annual average water content of NDS and DS was $81.0 \%$ and $80.8 \%$ in 2014 , respectively. Based on this, in the amount of gas generated per actual dry weight and sludge dry weight amounts, the SS is 4.5 times that of the DS and $31.4 \%$ of the NDS - even when converted to the dry weight sludge. As a result, when NDS is solidified and produced as SS, it is reduced to about one third, but it still shows a high gas generation rate.

The results of the BMT test of waste soil also showed that gas generation did not occur within the measurable range. Table 7 shows the results of the composition analysis on waste soil in demolition waste. In the result of the leaching experiment, the concentration of heavy metals was not at a level that inhibited anaerobic digestion. First, whether it is biodegradable or not, the combustible ratio of the waste only accounts for $11.6 \%$, the $\mathrm{BOD} / \mathrm{COD}$ ratio is 0.34 , which is very low for anaerobic digestion, and above all, the $\mathrm{pH}$ is 10.2 . These conditions make it harder for waste soil to produce more biogas. Table 8 shows the

Table 6. Ingredient of sludge solidification agent ${ }^{1}$.

\begin{tabular}{|c|c|c|c|c|c|c|c|}
\hline & Ingredient & Mixing ratio (\%) & $\mathrm{SiO}_{2}$ & $\mathrm{Al}_{2} \mathrm{O}_{3}$ & $\mathrm{Fe}_{2} \mathrm{O}_{3}$ & $\mathrm{CaO}$ & $\mathrm{MgO}$ \\
\hline \multirow{4}{*}{ SS } & Waste concrete sludge & $50 \sim 60$ & 67.1 & 11.30 & 3.10 & 5.53 & - \\
\cline { 2 - 9 } & Biomass dust & $19 \sim 27$ & 42.60 & 12.10 & 5.10 & 11.30 & 1.71 \\
\cline { 2 - 9 } & Cement $^{2)}$ & $1 \sim 3$ & 19.45 & 4.85 & 3.79 & 61.37 & 2.92 \\
\cline { 2 - 9 } & Sewage sludge ash & $10 \sim 20$ & 34.90 & 17.20 & 9.00 & 10.30 & - \\
\hline \multirow{5}{*}{ SLCM } & Pulp ash & $40 \sim 60$ & 21.30 & 14.30 & 6.65 & 44.30 & 3.40 \\
\cline { 2 - 9 } & Silica powder & $7 \sim 15$ & 86.50 & 6.45 & 2.10 & 0.67 & 0.51 \\
\cline { 2 - 9 } & Blast furnace slag & $7 \sim 10$ & 11.95 & 3.57 & 32.40 & 35.19 & 7.01 \\
\cline { 2 - 9 } & Biomass dust & $2 \sim 10$ & 42.60 & 12.10 & 5.10 & 11.30 & 1.71 \\
\cline { 2 - 9 } & Quicklime & $10 \sim 15$ & - & - & - & 95.20 & - \\
\cline { 2 - 9 } & Waste zeolite & $10 \sim 15$ & 44.00 & 51.00 & 0.66 & 0.30 & 0.14 \\
\hline
\end{tabular}

1) Sudokwon Landfill Site Management Co.

2) Afshinnia et al., 2015 
Table 7. Characteristics of waste soil from demolition waste*

\begin{tabular}{|c|c|c|}
\hline \multicolumn{2}{|l|}{ Item } & Analysis values \\
\hline \multirow{3}{*}{$\begin{array}{l}\text { Physical components } \\
(\%)\end{array}$} & Moisture & 13.08 \\
\hline & Combustibles & 11.63 \\
\hline & Incombustibles & 75.29 \\
\hline \multirow{6}{*}{$\begin{array}{l}\text { Water quality of eluate } \\
\qquad(\mathrm{mg} / \mathrm{L})\end{array}$} & $\mathrm{COD}_{\mathrm{cr}}$ & 1,859 \\
\hline & BOD & 583 \\
\hline & $\mathrm{T}-\mathrm{N}$ & 123.0 \\
\hline & T-P & 15.9 \\
\hline & $\mathrm{NH}_{4}^{+}-\mathrm{N}$ & 40.0 \\
\hline & $\mathrm{pH}$ & 10.2 \\
\hline \multirow{7}{*}{$\begin{array}{l}\text { Heavy metal in eluate } \\
\qquad(\mathrm{mg} / \mathrm{kg})\end{array}$} & $\mathrm{Cd}$ & 2.1 \\
\hline & $\mathrm{Cu}$ & 133.8 \\
\hline & As & 6.9 \\
\hline & $\mathrm{Hg}$ & 2.4 \\
\hline & $\mathrm{Pb}$ & 120.3 \\
\hline & $\mathrm{Zn}$ & 288.8 \\
\hline & $\mathrm{Ni}$ & 40.1 \\
\hline
\end{tabular}

*Sudokwon Landfill Site Management Co.

analysis results on ash-filled reactors. As shown in Table 8 , most of the ash consists of incombustibles and has a $\mathrm{pH}$ level of 9.5. This is not enough to be considered for biodegradability.

Table 8. Analysis result of ash.

\begin{tabular}{|c|c|c|}
\hline \multirow{4}{*}{$\begin{array}{c}\text { Physical } \\
\text { components }\end{array}$} & Moisture & Analysis values \\
\cline { 2 - 3 } & Combustibles & 20.3 \\
\cline { 2 - 3 } & Incombustibles & 74.9 \\
\hline \multirow{7}{*}{$\begin{array}{c}\text { Heavy metals } \\
(\mathrm{mg} / \mathrm{kg})\end{array}$} & $\mathrm{As}$ & 0.0 \\
\cline { 2 - 3 } & $\mathrm{Ca}$ & $99,548.3$ \\
\cline { 2 - 3 } & $\mathrm{Cd}$ & 0.1 \\
\cline { 2 - 3 } & $\mathrm{Cr}$ & 347.9 \\
\cline { 2 - 3 } & $\mathrm{Cu}$ & 404.5 \\
\cline { 2 - 3 } & $\mathrm{Fe}$ & $20,102.1$ \\
\cline { 2 - 3 } & $\mathrm{K}$ & $6,797.3$ \\
\cline { 2 - 3 } & $\mathrm{Mg}$ & $3,986.0$ \\
\cline { 2 - 3 } & $\mathrm{Mn}$ & 344.4 \\
\cline { 2 - 3 } & $\mathrm{Na}$ & $17,180.0$ \\
\cline { 2 - 3 } & $\mathrm{Pb}$ & 124.6 \\
\cline { 2 - 3 } & $\mathrm{Zn}$ & 863.8 \\
\hline
\end{tabular}

In the case of B1, cumulative gas generation amount was $12.8 \mathrm{~L} /$ wet $\mathrm{Kg}$. On the other hand, the amount of gas generated in the $\mathrm{B} 2$ and $\mathrm{B} 3$ reactors was negligible. Considering that there is almost no gas generation from the waste soil, and that $43.8 \%$ of waste soil is included in the B1 as shown in Table 3, the amount of gas generated by $\mathrm{SS}$ in $\mathrm{B} 1$ is estimated to be $29.2 \mathrm{~L} /$ wet $\mathrm{kg}$, and this value is very similar to that of SS, which is $29.6 \mathrm{~L} / \mathrm{wet} \mathrm{kg}$.

If the amount of volatilization into the gas phase during the solidification process is ignored, the composition ratio of SS produced is $54.5 \%$ moisture, $24.0 \%$ sludge, and $21.5 \%$ solidifying agents. Also, SLCM could be $47.6 \%$ moisture, $16.8 \%$ sludge, and $35.6 \%$ solidifying agents. In order to turn the LS3 into a landfill disposal site of incombustibles with virtually no gas generation, the SS should be used in energy or resource recovery systems other than landfills. Although SLCM is solidified enough to be used as a cover material, it generates very low volumes of biogas when buried. However, since it uses solidifying agents more than twice the amount of sludge on a dry weight basis, it can be considered practically the same as a solidifying agent. Therefore, it is also desirable to recycle it for other purposes in order to extend the life of the landfill, and to make reasonable reuse of resources.

On the other hand, for the household wastes in Korea, only combustibles from it are to be bagged and transported to incineration facilities or landfills. Therefore, household wastes brought into the LS2 are likely to produce RDF or SRF [19] by some mechanical sorting. However, for the demolition wastes, it is difficult to technically and economically operate the energy conversion or recovery, because the ratio of combustibles in the demolition waste is lower than that of household waste, and it needs to go through a mechanical sorting process due to different sizes and the characteristics of the incombustibles exiting in demolition wastes. For these reasons, instead of landfill disposal for energy recovery, the demolition wastes can be separately landfilled. The estimated result of the separate landfill disposal of demolition wastes can be drawn from the case of B4. The cumulative gas generation of B4 turned out to be $4.46 \mathrm{~L} /$ wet $\mathrm{kg}$, which is much smaller than $\mathrm{B} 1$.

In the case of demolition waste, $1.2 \times 10^{6}$ ton was buried in LS2 in 2014, which is about $50 \%$ of the total landfill. Taking this into account to calculate the cumulative gas generation, the case of B1, in which a combination of SS and waste soil left from energy recovery of demolition waste is landfilled, shows 1.8 times larger gas generation than that of the case of B4, in which demolition wastes are landfilled separately.

In conclusion, the BMP test results show that ash left from energy recovery processes - such as incineration of combustible wastes that come from household and demolition wastes and waste soil left from mechanical sorting of demolition waste, and sludge turned into cover soil materials - have no gas generation properties. But the solidified sludge generates enough biogas to warrant further studies. Therefore, in order to operate the LS3 as a landfill without considering landfill gas production, 
it is necessary to increase the amount of solidifying agents such as increasing the ratio of $\mathrm{Ca}$ in the process of making $\mathrm{SS}$, or to introduce other recycling methods for sludge instead of solidification [20]. In addition, demolition waste has a disadvantage in the biodegradation condition. Therefore, it is difficult to produce enough biogas to secure economic efficiency in an LFG-producing landfill. It only causes a longer stabilization period due to low degradability and a decrease in the capacity of landfills of other incoming wastes. Therefore, it is necessary to recover thermochemical energy by separation and sorting, as in the case of household waste.

\section{Estimating Total Amount of LFG After Energy Recovery}

The total cumulative gas production $\left(\mathrm{CH}_{4}\right.$ and $\left.\mathrm{CO}_{2}\right)$ was estimated through a lysimeter experiment. From the beginning of the experiment, rapid gas production occurred in L1 and the cumulative gas generated at the end of the 205 days of the experiment was $293.2 \mathrm{~L}$. In L2, gas production started relatively late, such that a measurable amount of gas was generated only from the $110^{\text {th }}$ day of the experiment. The total cumulative gas generation in L2 at the end of the 205 days of the experiment was $20.2 \mathrm{~L}$. This means that the amount of organic matter in L2 is smaller than that of the currently reclaimed wastes in LS2. In addition, the average $\mathrm{pH}$ of L1 was 6.5, while L2 was 9.5. These differences can be explained by the ash, waste soil, or any other residues left from the energy recovery processes that cannot suit landfill biogas production.

The amounts of filling waste in L1 and L2 were $10.4 \mathrm{~kg}$ and $10.3 \mathrm{~kg}$ on a wet basis. In addition, nonbiodegradable materials such as plastics and bricks were excluded for efficient experiments. Therefore, as shown in Table 9, when calculating the amount of gas generated per unit weight of the actual waste, it is necessary to reconsider the portion of the packing with exclusion of the non-biodegradable materials. In this case, L1 produced 9.7 times more gas per unit weight of waste than L2. In consideration of the total amount of landfill in the actual field, the gas production of L1 was 26.7 times that

Table 9. Estimation of real conditions of biogas production.

\begin{tabular}{|c|c|c|}
\hline Biogas generation & L1 & L2 \\
\hline Biogas Generation (NL/wet kg) ${ }^{1}$ & 28.14 & 1.97 \\
\hline Corr. Biogas Generation (NL/wet kg) ${ }^{2}$ & 19.04 & 1.97 \\
\hline Total Landfill Waste $\left(10^{3} \mathrm{Mg}\right)$ & 2,431 & 881 \\
\hline Total LFG production $\left(10^{3} \mathrm{Nm}^{3}\right)^{3}$ & 46,279 & 1,735 \\
\hline
\end{tabular}

1) The amount of gas generated per unit weight of the sample

2) The amount of gas converted into mass per unit, mass of household waste, reflecting the non-reactive materials (plastics and incombustibles) in household and demolition wastes, respectively, of $46.3 \%$ and $32.5 \%$

3) Estimated amount of real biogas production of L2. In other words, the lysimeter test results showed that only incombustibles such as ash and waste soil were buried, and also that the sludge is solidified before landfilling. Therefore, the production of $\mathrm{CH}_{4}$ and $\mathrm{CO}_{2}$ were reduced to $1 / 27$ of the level currently produced.

In L2, the amount of LFG decreased significantly, but the decline was not sufficient for the operation of a landfill without the LFG collection facility. Furthermore, the production of LFG was not sufficient for running a profitable LFG power plant [21]. For example, SLS obtains $50 \mathrm{MW}$ of energy from the LFG power plant, but the incoming wastes in LS2 are decreasing annually due to the waste control policy, which means that the incoming waste in LS3 would be much less than that in LS2. Moreover, this can lead to a very small generation of only $1 \mathrm{MW}$ or less when LS3 is used for LFG production. However, an expensive LFG collection system still has to be installed at LS3, which may be considered very inefficient and uneconomical. Therefore, more thorough energy and resource recovery projects are needed.

\section{Influence of Energy Recovery on $\mathrm{H}_{2} \mathrm{~S}$ Generation}

More than 100 odor-inducing substances exist in landfills, of which $\mathrm{H}_{2} \mathrm{~S}$ is the most important. $\mathrm{H}_{2} \mathrm{~S}$ generated in landfills not only causes odor through surface emission [22-23], but is also toxic to the human body at 100-200 ppm levels [24-25].

In addition, the problems of pre-treatment of $\mathrm{H}_{2} \mathrm{~S}$ in LFG power generation, the exhaustion of sulfur dioxide into the atmosphere during incineration, and corrosion of various other landfill gas management systems exist [26]. $\mathrm{H}_{2} \mathrm{~S}$ occurs during the biochemical metabolism of sulfate in landfill wastes. Approximately 3-5\% of gypsum exists in cement from demolition waste, and it can be reduced to $\mathrm{H}_{2} \mathrm{~S}$ by sulfate-reducing bacteria (SRB) in the presence of an appropriate level of organic matter $\left(\mathrm{CH}_{2} \mathrm{O}\right)$ [27-28] as in Eq. 3 [29].

$$
\mathrm{SO}_{4}{ }^{2-}+2\left(\mathrm{CH}_{2} \mathrm{O}\right) \rightarrow \mathrm{H}_{2} \mathrm{~S}+2 \mathrm{HCO}_{3}^{-}
$$

Therefore, for landfills that accept demolition waste, the $\mathrm{H}_{2} \mathrm{~S}$ concentration can reach 50,000-100,000 ppm [30]. LS2, which contained a mixture of demolition and household waste, also had a very high average annual $\mathrm{H}_{2} \mathrm{~S}$ concentration of $11.5 \times 10^{3} \mathrm{ppm}$ in 2014 , reaching $20,000 \mathrm{ppm}$ at certain times. Therefore, to suppress the surface emission of $\mathrm{H}_{2} \mathrm{~S}$, the cover soil was regularly updated, and the LFG collection was increased. As a result, the 2014 annual report showed that the external influx in LFG reached $16.7 \%$. Excessive external influx causes problems such as the explosion of $\mathrm{CH}_{4}$ due to oxygen inflow, oxidation of $\mathrm{CH}_{4}$ [31], increases in the collection system load, and decreases in the caloric value of landfill gas.

In the case of $\mathrm{L} 1$, the concentration of $\mathrm{H}_{2} \mathrm{~S}$ reached $60.9 \times 10^{3} \mathrm{ppm}$ on the $108^{\text {th }}$ day of the experiment. The concentration was higher than $10,000 \mathrm{ppm}$ even after 
Table 10. LS2 Sulfate content in landfill waste materials.

\begin{tabular}{|c|c|c|c|c|c|c|c|c|c|c|c|}
\hline \multirow{2}{*}{ Total } & \multicolumn{4}{|c|}{ Household waste } & \multicolumn{4}{c|}{ Demolition waste } \\
\cline { 2 - 27 } & Sub total & Food & Paper & Wood & Textile & Other & Sub total & Paper & Wood & Textile & Waste soil \\
\hline $347.6\left(10^{3} \mathrm{Mg}\right)$ & 10.7 & 2.2 & 4.4 & 1.3 & 2.2 & 0.6 & 337.0 & 7.9 & 32.1 & 3.6 & 293.3 \\
\hline $100 \%$ & 3.1 & 0.6 & 1.3 & 0.4 & 0.6 & 0.2 & 96.9 & 2.3 & 9.2 & 1.0 & 84.4 \\
\hline
\end{tabular}

178 days. On the other hand, L2 showed a relatively low concentration of less than $200 \mathrm{ppm}$ until the $94^{\text {th }}$ day of the experiment, and showed a peak concentration of $9.7 \times 10^{3} \mathrm{ppm}$ after 127 days, and then decreased to about $73.8 \mathrm{ppm}$ after 178 days.

Table 10 shows the sulfur content calculated based on the elemental analysis data of each waste material landfilled in LS2 until the end of 2014 after the landfill started in October 2000. As shown in the table, 96.9\% of the total amount of landfill is due to demolition waste. $84.4 \%$ of the total amount of LS2 sulfur of landfill waste comes from the waste soil of demolition waste, and it can be said that the waste soil that has a large amount of gypsum is the main source of $\mathrm{H}_{2} \mathrm{~S}$.

The amount of sulfate in L1 and L2 does not differ much. However, the concentration of $\mathrm{H}_{2} \mathrm{~S}$ was relatively high in L1 because there was more organic matter than in L2. Therefore, when there is no other recycling method for waste soil from mechanical sorting of demolition waste, in order to prevent $\mathrm{H}_{2} \mathrm{~S}$ generation, the waste soil should be separated from other wastes that can provide organic matter for causing reactions.

However, in addition to the concentration of $\mathrm{H}_{2} \mathrm{~S}$ generation, the total amount of gas generation is important. This is because the discharge load multiplied by the concentration and the amount of gas generation is a substantial pollutant load. The calculated amount of $\mathrm{H}_{2} \mathrm{~S}$ generation load for L2 was significantly reduced to $0.9 \%$ of L1. In particular, as mentioned above, when the SS is not landfilled, there is no organic supply from the $\mathrm{SS}$, and the amount of landfill gas generated is very small. Therefore, the problem of $\mathrm{H}_{2} \mathrm{~S}$ generation was considered to be solved.

\section{Conclusions}

The effect on the LFG in newly built landfill sites by the application of practical energy recovery processes is studied using the example of the landfill sites in Korea. As a result of the BMP test, even if the waste composition is made up of the same biodegradable materials such as paper, wood, and fiber, the amount of biogas generated from demolition wastes was much smaller than that generated from household wastes. In addition, SLCM, ash produced after thermal energy recovery from wastes, and waste soil from mechanical pretreatment of demolition waste were almost free of gas. On the other hand, gas generation by SS was 4.1 times that of the DS per unit weight and $35.9 \%$ of the NDS. This is because the amounts and components of the solidifying agents are not suitable for sludge solidification by the pozzolanic reaction. The results of the lysimeter experiments showed that the total amount of LFG would be reduced to about $1 / 27$ when the residues and ash from the energy recovery of combustible wastes were mainly landfilled (L2) compared to current direct landfill of all income wastes. Considering the cost issues, the amount of LFG was found to be insufficient for properly running a profitable LFG power generation system. Therefore, in order to omit the LFG collection system at the new landfill site, it is desirable that the SS, which is the only gas generation source, should be recycled in a different manner and not landfilled. The mixed waste landfill (L1) showed that the maximum concentration of $\mathrm{H}_{2} \mathrm{~S}$ was $60.9 \times 10^{3} \mathrm{ppm}$, and the maximum concentration of L2 was still $9.7 \times 10^{3} \mathrm{ppm}$ due to the supply of organic matter from SS. However, since the total amount of LFG generation decreased in L2 due to the application of energy recovery systems, the total generation load of $\mathrm{H}_{2} \mathrm{~S}$ was greatly reduced to $0.9 \%$ of L1.

\section{References}

1. RASI S., LANTELA J., RINTALA J. Upgrading landfill gas using a high pressure water absorption process. Fuel 115, 539, 2014.

2. KHAIRUDDIN N., MANAF L.A, HASSAN M.A, HALIMOON N., KARIM W.A.W.A. Biogas Harvesting from Organic Fraction of Municipal Solid Waste as a Renewable Energy Resource in Malaysia: A Review. Pol. J. Environ. Stud. 24 (4), 1483, 2015.

3. VAVERKOVÁ M., ADAMCOVÁ D. Long-Term Temperature Monitoring of a Municipal Solid Waste Landfill. Pol. J. Environ. Stud. 24 (3), 1373-1374, 2015.

4. MA J., ZHAO Y., WANG J., WANG L. Effect of magnesium oxychloride cement on stabilization/ solidification of sewage sludge. Demolition Building Mater. 24, 79, 2010.

5. XIN D., CHAI X., ZHAO W. Hybrid cement-assisted dewatering, solidification and stabilization of sewage sludge with high organic content. J. Mater. Cycles Waste Manage. 18 (1), 356, 2016.

6. SUCHOWSKA-KISIELEWICZ M., JĘDRCZAK A., MYSZOGRAJ S. Kinetic constants of decomposition of the municipal solid waste prior to and after mechanicalbiological processing. Field scale. Archives environ. Prot. 38 (4), 71, 2012.

7. MOU Z., SCHEUTZ C., KJELDSEN P. Evaluating the biochemical methane potential (BMP) of low-organic waste at Danish landfills. Waste Manage. 34 (11), 2254, 2014. 
8. DEIPSER A., STEGMANN R. The Origin and Fate of Volatile Trace Components in Household Solid Waste Landfills. Waste Manage. Res. 12, 131, 1994.

9. AHMED A.T., KHALID H.A., AHMED A.A., CHEN D. lysimeter experimental study and numerical characterization of the leaching of incinerator bottom ash waste. Waste Manage. 30, 1537, 2010.

10. HE J., LI F., LI Y., CUI X. Modified sewage sludge as temporary landfill cover material. Water Sci. Eng. 8 (3), 259, 2015.

11. SUN F., WU S., LIU J., LI B., CHEN Y., WU W. Denitrification capacity of a landfilled refuse in response to the variations of $\mathrm{COD} / \mathrm{NO}_{3}-\mathrm{N}$ in the injected leachate. Bioresour. Technol. 103, 112, 2012.

12. BHATTACHARYA S.K., UBEROI V., DRONAMRAJU M.M. Interaction between acetate fed sulfate reducers and methanogens. Water Res. 30 (10), 2239, 1996.

13. YUCHENG C.A.O., STASZEWSKA E. Role of landfill cover in reducing methane emission. Archives environ. prot. 39 (3), 115, 2013.

14. YUE D., HAN B., SUN Y., YANG T. Sulfide emissions from different areas of a household solid waste landfill in China. Waste Manage. 34, 1041, 2014.

15. FILIPKOWSKA U. Effect of Recirculation Method on Quality of Landfill Leachate and Effectiveness of Biogas Production. Polish J. of Environ. Stud. 17 (2), 200, 2008.

16. FILIPKOWSKA U., AGOPSOWICZ M.H. Solids Waste Gas Recovery Under Different Water. Pol. J. Environ. Stud. 13 (6), 664, 2004.

17. JANIN A., COUDERT L., RICHE P., MERCIER G., COOPER P., BLAIS J.F. Application of a CCA-treated wood waste decontamination process to other. copperbased preservative-treated wood after disposal. Hazard Mater. 186, 1880, 2011.

18. KRÄMER C., KOWALD T.L., TRETTIN R.H.F. Pozzolanic hardened three-phase-foams. Cement Concr. Composites 62, 45, 2015.

19. LONARDO M.C.D., FRANZESE M., COSTA G., GAVASCI R., LOMBARDI F. The application of SRF vs. RDF classification and specifications to the material flows of two mechanical-biological treatment plants of Rome:
Comparison and implications. Waste Manage. 47, 195, 2016.

20. TYAGI V.K., LO S.L. Sludge: A waste or renewable source for energy and resources recovery. Renew. Sustainable Energy Reviews. 25, 723, 2013.

21. GEWALD D., SIOKOS K., KARELLAS S., SPLIETHOFF $\mathrm{H}$. Waste heat recovery from a landfill gas-fired power plant. Renew. Sustainable Energy Reviews. 16, 1786, 2012.

22. KIM K.H., CHOI Y.J., JEON E.C., YOUNG S.W. Characterization of malodorous sulfur compounds in landfill gas. Atmospheric Environ. 39 (6), 1107, 2005.

23. HEANEY C.D., WING S., CAMPBELL R.L., CALDWELL D., HOPKINS B., RICHARDSON D., YEATTS K. Relation between malodor, ambient $\mathrm{H}_{2} \mathrm{~S}$, andhealth in a community bordering a landfill. Environ. Res. 111 (6), 848, 2011.

24. GLASS D.C. A review of the health effects of hydrogen sulphide exposure. Annals Occup. Hyg. 34, 323, 1990.

25. LEGATOR M.S., SINGLETON C.R., MORRIS D.L., PHILIPS D.L. Health effects from chronic low-level exposure to hydrogen sulfide. Archives Environ. Health 56 (2), 123, 2001.

26. SUN W., SUN M., BARLAZ M.A. Characterizing the biotransformation of sulfur-containing wastes in simulated landfill reactors. Waste Manage. 53, 82, 2016.

27. DE SMUL A., GOETHALS L., VERSTRAETE W. Effect of COD to sulphate ratio and temperature in expandedgranular-sludge-blanket reactors for sulphate reduction. Process Biochem. 34, 408, 1999.

28. BHARATI B., PRANAB K.G. Sulfate bioreduction and elemental sulfur formation in a packed bed reactor. J. Environ. Chem. Eng. 2(3), 1287, 2014.

29. HAO J.O., JIN M.C., LI H. Sulfate-reducing bacteria. Crit. Review Environ. Sci. Technol. 26, 155, 1996.

30. PLAZA C., XU Q., TOWNSEND T., BITTON G., BOOTH M. Evaluation of alternative landfill cover soils for attenuating hydrogen sulfide from demolition and demolition (C\&D) debris landfills. J. Environ. Manage. 84 (3), 314, 2007.

31. CHUN S.K. The influence of air inflow on $\mathrm{CH}_{4}$ composition ratio in landfill gas. J Mater Cycles Waste Manage. 16 (1), 172, 2014. 